\title{
Nanotechnology-Based Materials Applied in Curtain Wall System: A Case Study from Turkey $\begin{gathered}\text { Osman Zeki Sahin" } \\ \text { reliz Tuluibas cokus" }\end{gathered}$
}

\begin{abstract}
Purpose

Application of nanotechnology in construction sector brings innovation to building materials like self-cleaning and antifog. These features make it possible to shorten the maintenance and repair periods of building materials, and thereby reduce maintenance costs. The development of environmentally friendly building materials become very important to reduce air pollution and adverse effects. The competitiveness of companies in the construction sector is based on technological developments. Now, it is possible to reduce costs and respond to various customer demands owing to new technologies. Nanotechnology affects many sectors as a technology that contributes significantly to the development of the properties of materials, and it has also found its place in the construction sector. The purpose of this study is to examine the use of nanomaterials used in the construction sector in the context of glass and curtain wall systems. Also, the aims of this paper are to reveal the advantages of nanomaterials by examining the differences between the traditional and the nanotechnology applications used in
\end{abstract} Keywords: Curtain wall system, glass curtain wall, aluminum curtain wall system, nano-products, nanotechnology

*MSc Student in Architecture, Balikesir University, Balikesir, Turkey.

E-mail: osmanzekisahin@gmail.com Orcid No: http://orcid.org/0000-00027542-9931

${ }^{* *}$ Asst. Prof. Dr. Faculty of Architecture, Department of Architecture, Balikesir University, Balikesir, Turkey, E-mail: yeliz@balikesir.edu.tr Orcid No: https://orcid.org/0000-00033594-7977 
glass and curtain wall systems, to remark nanomaterial applications in construction sector, and finally to expand awareness in this regard.

\section{Design/Methodology/Approach}

This study consisted in reviewing existing nanomaterials in the curtain wall system applications through projects, and conducting a survey. A preliminary letter and a 14-question survey were prepared. This study covers aluminum composite and glass curtain wall suppliers which were contacted by email. Face to face interviews were made with those who could not be reached by e-mail. The survey that was formed by the authors was sent to 68 participants working in the aluminum composite and glass curtain wall companies operating in the construction sector.

\section{Findings}

The findings of the study show that there are a limited number of structures using nanomaterials in Turkey. While these materials are used in many different parts of the structures, the most preferred in the outer shell design of the buildings (curtain wall systems).The construction sector should be considered as one of the critical sectors where nanotechnology can be practiced.

\section{Research Limitations/Implications}

The paper contains the normal limitations associated with the survey method including potential non-response bias.

\section{Practical Implications}

Potential of nanotechnology applications is growing in the construction field. There are large numbers of nanotechnology applications in the sector. However, construction sector is a traditional and cost oriented industry, rather than a technology focused sector. High cost of nanotechnology-based materials is a major obstacle to applications of nanotechnology in the construction sector. Even though some steps have been taken in the field of nanotechnology, the sector should be supported with incentives by government and research institutions.

\section{Social Implications}

The construction sector is the largest sector that causes environmental problems through construction, operation and maintenance of buildings. Due to its potential contribution to sustainability, it makes nanotechnology one of the most promising technologies in the green building area. Nanotechnology has much to offer the construction industry as it moves towards a more sustainable future. The effects of nanotechnological materials on the environment and human health are not clearly defined yet. More studies needed about that.

\section{Originality/Value}

Performing such a study is considered to be crucial for construction sector of developed and developing countries, so that the construction sector also avails benefits from this revolutionary technology.

\section{INTRODUCTION}

Nanotechnology is considered as the most important and fast developing technology of the twenty-first century. It has a strategic importance for countries, most particularly in the global competition environment. Nanotechnology brings innovation in many areas like medical sciences, materials 
science, defense industry, textiles, economics, computers, clean energy sources, sustainable energy, environment and food etc. Nanotechnology, which has the potential to foster in many disciplines, also takes place in construction sector in terms of production and use of nanomaterials. In the field of architecture, there have been considerable amount of constructive developments with the help of nanotechnology. It aims to develop stronger, better quality, longer lasting, cheaper and lighter construction materials comparing to traditional materials. The nanotechnology-based materials used for the construction is the pioneer of the developments in the field of architecture and construction sector. It is found that the implementation of nanomaterials in buildings has great benefits in construction sector. Nanotechnology reduces both weight and volume of conventional materials, also allows the usage of materials more efficiently. Throughout the development, the new features that introduced into the materials prevent the damage, so that the necessity of maintenance and repair are reduced. As the production processes are decreased; resources are protected, raw materials and energy consumption are decreased.

The competitiveness of companies in the construction sector is based on technological developments. Now, it is possible to reduce costs and respond to various customer demands owing to new technologies. Nanotechnology affects many sectors as a technology that contributes significantly to the development of the properties of materials, and it has also found its place in the construction sector. The nanotechnology product market is growing at an ever increasing rate, and it is foreseen that nanotechnology will be one of the most important technology that will affect the global economy in the next 20 or 30 years (Özenbaș, 2006). Research studies have shown that nanotechnology can be a pioneer in improving the performance of traditional building materials such as concrete and steel. The construction sector is the largest sector that causes environmental problems through construction, operation and maintenance of buildings (Dixon, 2010; Enshassi et al. 2014). Due to its potential contribution to sustainability, it makes nanotechnology one of the most promising technologies in the green building area (Raj et al.,2017). Although nanomaterials are ready to be used widely in the construction sector, they have not made a significant impact in the sector, yet. This study explores the potential use of nanomaterials that can be used in the near future for curtain wall systems. The aim of this study is to determine the use of products improved by nanotechnology in glass and curtain wall systems. Also, to reveal the advantages of incorporating nanotechnology into a product, and to expand awareness on this issue by examining the differences between 
the traditional and the nanomaterial applications used in glass and curtain wall system are the other purposes of the study.

Understanding the adaptation of nanotechnology into the glass and curtain wall system, and evaluating the existing nanotechnology applications have great importance. This study consisted in reviewing existing nanomaterials in the curtain wall system applications, and then conducting a survey. This survey, which aimed to reveal how much nanomaterials are used in the curtain wall systems in Turkey, conducted among aluminum composite and curtain wall system suppliers.

\section{NANOTECHNOLOGY}

Nanotechnology involves the creation of materials and devices with novel or unusual properties by individual atoms or molecules. While combining science, physics, chemistry and biology with different engineering branches such as electronics, industry, mechanics, space, computer, building sector, it leads all disciplines to think at the molecular level in their own fields, then design into products. This view has increased the interest in nanotechnology, so that studies in this area have gained momentum (URL1; Tepe, 2007).

Nano comes from the Greek word "nanos," meaning dwarf. Nanomaterials have been defined as the materials which at least one of its dimensions is below $10 \mathrm{~nm}$ (Daryoush \& Darvish, 2013). The nanotechnology field was conceived by Richard Feynman in 1959 at the annual meeting of the American Physical Society. The development of nanotechnology was induced by his lecture called "There is plenty of room at the bottom". The concept of nano-scale has revealed for the first time in the world. Feynman explained that atoms and molecules can be used in very small sizes by changing structures with very sensitive instruments. However, the name of this process, which was described at that time, has not been named as nanotechnology. In 1974, Norio Taniguchi introduced the term nanotechnology at an engineering conference in Tokyo. According to him, nanotechnology is mainly consisting of separation, consolidation, and deformation of materials by one atom or one molecule (Taniguchi, 1974). Nanotechnology is a thriving field of research with far-reaching implications for novel applications. Physics, chemistry, biology, engineering and many more disciplines feed the development of nanotechnology and related studies.

\section{NANOTECHNOLOGY IN CONSTRUCTION SECTOR}

Nanotechnology represents a major opportunity for the construction sector to develop new products, substantially increase quality, and open new markets (Halicioglu, 2009). The early applications of nanotechnology materials in the 
construction sector was seen in the mid-90s (Bozoglu \& Arditi, 2012). After the first-generation nanomaterials were introduced to the construction markets, a forum was formed for discussing related studies in order to evaluate the potential and develop more realistic applications. The International Symposium on Nanotechnology in Construction, which held in Scotland in 2003, was the first event to combine the topics of nanotechnology and construction. As a conlucsion of this event, The Roadmap for Nanotechnology in Construction (RoNaC) was introduced as an aid for further applications, forecasting research and investment directions.

Many studies highlight the importance of nanotechnology (Sev \& Ezel, 2014; Hossain \& Rameeja, 2015; Olafusi et al. 2019; Tülübaş Gökuç \& Turunç, 2019; Das et al. 2020; Ali, 2020). The implementations of nanotechnology materials mainly depend on large chemical companies. However, it could be stated that the demand for the nanomaterials is limited in the construction sector. The significance of nanomaterial implementations in the construction sector has not been clearly defined until recently. Comparing to other industrial sectors, the utilization of nanotechnology in the construction sector has been dropped behind due to the lack of awareness of its potential (Bartos, 2009). It is clear that it should be established a better understanding of the benefits of utilizing this innovative and promising technology. The fact that building and construction materials should be lighter and more durable than it's now, besides more flexible, longer lasting, and less harmful to the environment during the production processes. Deploying the latest techniques of nanotechnology relevant to construction materials will make a powerful contribution in the development of nanomaterials with these promising features (Candemir et al., 2012).

The most important materials that are used in civil constructions are concrete, steel, wood, and glass (Da Silva et al., 2011). With the developments in the field of nanotechnology, high performance construction materials can be obtained by mixing nanoscale materials with concrete or steel. Nanoscale materials have very different properties compared to macro scale materials. For instance, carbon nanotube, one of the most important nanomaterials, is approximately 100 times stronger and six times lighter than steel (Niroumand et al. 2013). One of the most important studies in construction sector is the nanocomposite research that aims to enhance the properties of concrete. Nanomaterials such as Titanium Dioxide $\left(\mathrm{TiO}_{2}\right)$, Carbon Nanotube, Nano Silica $\left(\mathrm{SiO}_{2}\right)$ and Nano-Alumina $\left(\mathrm{Al}_{2} \mathrm{O}_{3}\right)$ can be used as concrete additive. These nanomaterials increase the strength and resistance of the building material by filling the 
empty spaces in the structure of the concrete. In addition, it has been found in many studies that hydration reaction in concrete production is accelerated by nanomaterials. Therefore, a new class of concrete composite with improved properties has been revealed by nanomaterials.

The main nanomaterials used in the construction sector are; Nano-Silica $\left(\mathrm{SiO}_{2}\right)$, Iron Oxide $\left(\mathrm{Fe}_{2} \mathrm{O}_{3}\right)$, Carbon Nanotubes (CNT), Silver Nanoparticles (AgNPs), Titanium dioxide $\left(\mathrm{TiO}_{2}\right)$, Copper Nanoparticles (CuNPs), Aluminum Oxide $\left(\mathrm{Al}_{2} \mathrm{O}_{3}\right)$, Clay, Magnesium Nanoparticles, and Aerogels. The construction sector benefits from the R\&D activities of other sectors to a great extent, and makes use of nanotechnology developments in the same way. In the early 1990s, a Delphi study that conducted in England emphasized the importance of using nanotechnology in the projections of Swedish and UK construction sectors (Zhu et al., 2004). However, it could be stated that the nanomaterial demand is still inadequate in the sector. The applications and innovations of nanomaterials mostly depend on the large chemical and materials science companies.

Nanomaterials used in construction, scope of applications and prospective benefits are given in Table 1 below. 
Nanotechnology-Based Materials Applied in Curtain Wall System: A Case Study from Turkey

Table 1. Nanomaterials used in construction, scope of applications and prospective benefits (expanded from Lee et al. 2010).

\begin{tabular}{|c|c|c|}
\hline Nanomaterials & $\begin{array}{l}\text { Scope of } \\
\text { Application }\end{array}$ & Prospective Benefits \\
\hline \multirow[t]{3}{*}{ Nano Silica $\left(\mathrm{SiO}_{2}\right)$} & Concrete & $\begin{array}{l}\text { Reinforcement in } \\
\text { mechanical strength }\end{array}$ \\
\hline & Ceramics & $\begin{array}{l}\text { Coolant; light } \\
\text { transmission; fire } \\
\text { resistant }\end{array}$ \\
\hline & Window & $\begin{array}{l}\text { Flame-proofing; } \\
\text { anti-reflection }\end{array}$ \\
\hline \multirow[t]{3}{*}{ Titanium Dioxide $\left(\mathrm{TiO}_{2}\right)$} & Cement & $\begin{array}{l}\text { Rapid hydration; } \\
\text { increased degree of } \\
\text { hydration; self- } \\
\text { cleaning }\end{array}$ \\
\hline & Window & $\begin{array}{l}\text { Superhydrophilicity; } \\
\text { anti-fogging; } \\
\text { fouling-resistance }\end{array}$ \\
\hline & Solar cell & $\begin{array}{l}\text { Non-utility } \\
\text { electricity } \\
\text { generation }\end{array}$ \\
\hline \multirow[t]{5}{*}{ Carbon Nanotubes (CNT) } & Concrete & $\begin{array}{l}\text { Mechanical } \\
\text { durability; crack } \\
\text { prevention }\end{array}$ \\
\hline & Ceramics & $\begin{array}{l}\text { Enhanced } \\
\text { mechanical and } \\
\text { thermal properties }\end{array}$ \\
\hline & NEMS/MEMS & $\begin{array}{l}\text { Real-time structural } \\
\text { health monitoring }\end{array}$ \\
\hline & Solar cell & $\begin{array}{l}\text { Effective electron } \\
\text { mediation }\end{array}$ \\
\hline & Nano sensors & $\begin{array}{l}\text { Real time } \\
\text { monitoring of } \\
\text { structures }\end{array}$ \\
\hline Silver Nanoparticles (Ag) & Coating/painting & Biocidal activity \\
\hline Copper Nanoparticles (Cu) & Steel & $\begin{array}{l}\text { Weldability; } \\
\text { corrosion } \\
\text { resistance; } \\
\text { formability }\end{array}$ \\
\hline Alumina & Concrete & $\begin{array}{l}\text { Improving } \\
\text { mechanical and } \\
\text { physical properties } \\
\text { of concrete }\end{array}$ \\
\hline $\mathrm{Fe}_{2} \mathrm{O}_{3}$ & Concrete & $\begin{array}{l}\text { increased } \\
\text { compressive } \\
\text { strength; abrasion- } \\
\text { resistant }\end{array}$ \\
\hline Clays & Asphalt & $\begin{array}{l}\text { Increasing the } \\
\text { viscosity of asphalt } \\
\text { binders and the } \\
\text { fatigue strength of } \\
\text { asphalt mixtures }\end{array}$ \\
\hline Quantum dots (CdSe) & Solar cell & $\begin{array}{l}\text { Solar Energy } \\
\text { Utlization }\end{array}$ \\
\hline Aerogels & Insulation & $\begin{array}{l}\text { Energy efficiency, } \\
\text { space savings, } \\
\text { moisture } \\
\text { management, design } \\
\text { flexibility }\end{array}$ \\
\hline
\end{tabular}
of concrete compressive strength; abrasionIncreasing the viscosity of asphal inders and the fatigue strength of Solar Energy Energy efficiency, management, design 


\section{USE OF NANOTECHNOLOGY IN GLASS CURTAIN WALL SYSTEMS AND SOME PROJECTS}

There are three applications of nanotechnology-based materials for glass surfaces; self-cleaning feature, heat resistance, and indoor climate control. Working principles are similar to paints and coatings (Candemir et al.,2012).

\section{Self-Cleaning Feature}

Since the glass structures are constantly exposed to dirt, surfaces must be formed to prevent dirt from adhering to the surface and to let water flow off more easily. By adding silver nanoparticles or Nano Silica $\left(\mathrm{SiO}_{2}\right)$ on glass surfaces, a hydrophobic state is formed similar to the lotus effect seen on the lotus flower, and the dirty particles flow together with rain. The Lotus effect takes its name from the lotus plant's self-cleaning feature. Water drops move from the leaf surface and clean the dirt, this phenomena is known as the Lotus effect. The Lotus Effect significantly reduces the need for cleaning, and furthermore the surfaces that exposed to water remain clean. Cleaner appearance and significantly reduced maintenance costs are some of the advantages of this feature.

Another method of producing self-cleaning glass is coating of Titanium Dioxide $\left(\mathrm{TiO}_{2}\right)$. With the help of UV light, photocatalytic reaction starts and rain can remove any dirt from glass (Figure 1).
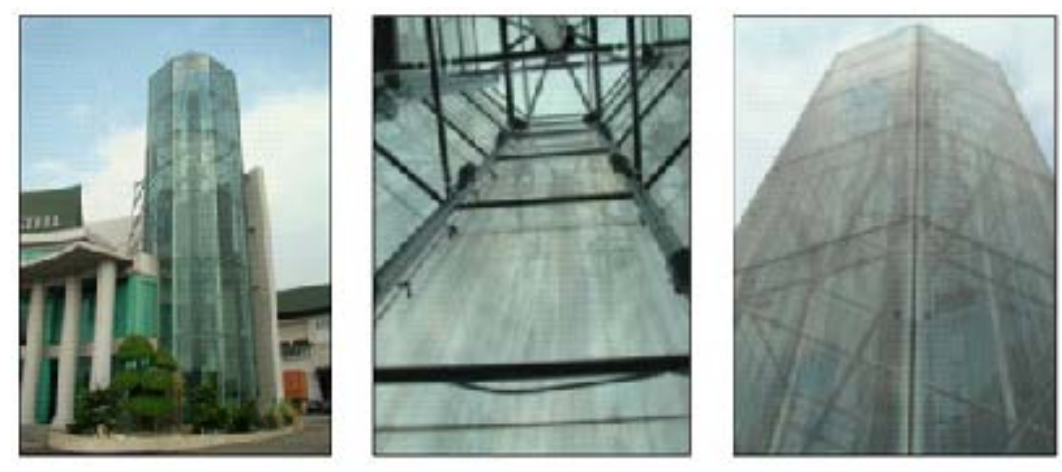

Figure 1. Photocatalyst $\mathrm{TiO}_{2}$ glass coating before and after application (URL2).
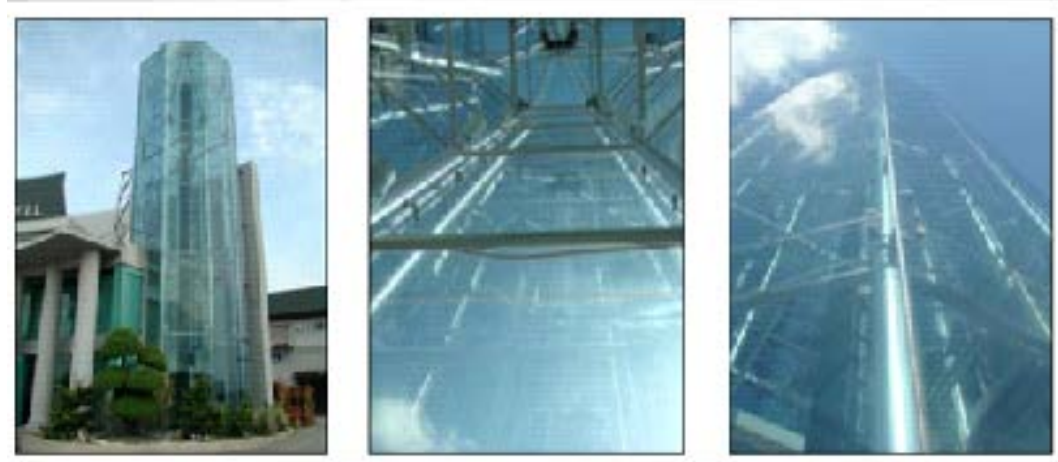


\section{Heat Resistance}

Coating the glass surface on with transparent and thin metal oxides, forming intermediate layer between the glass panels by adding fumed silica that lets the expansion in the case of temperature increases are the leading applications in the field of fire and heat resistance in glasses. Fire-resistant nano-glass is produced by using aerosol material in the form of filler material between several layers of glass. When the intermediate materials in the form of gels placed between the glass layers are exposed to flames, these materials become opaque and create thermal insulation. Thus, it is ensured that nano-glasses are effective against fire (Gür,2010).

In addition to being resistant to fire for a certain period of time, nano-glasses have some other advantages of being thin and light, high light transmittance, resistance to impacts, and being resistant to ultraviolet rays. Fire resistant nano-glasses are generally preferred in high-rise buildings, also in some certain areas (corridors, floors, foyers) that require fire safety. Located in Bonn, Germany, the Deutsche Post Headquarters is a striking building which is 160 meters high with more than two thousand employees (Figure 2). In the construction of the building, nanoglasses were used to provide protection against fire for both exterior and interior glass walls (Gür,2010).

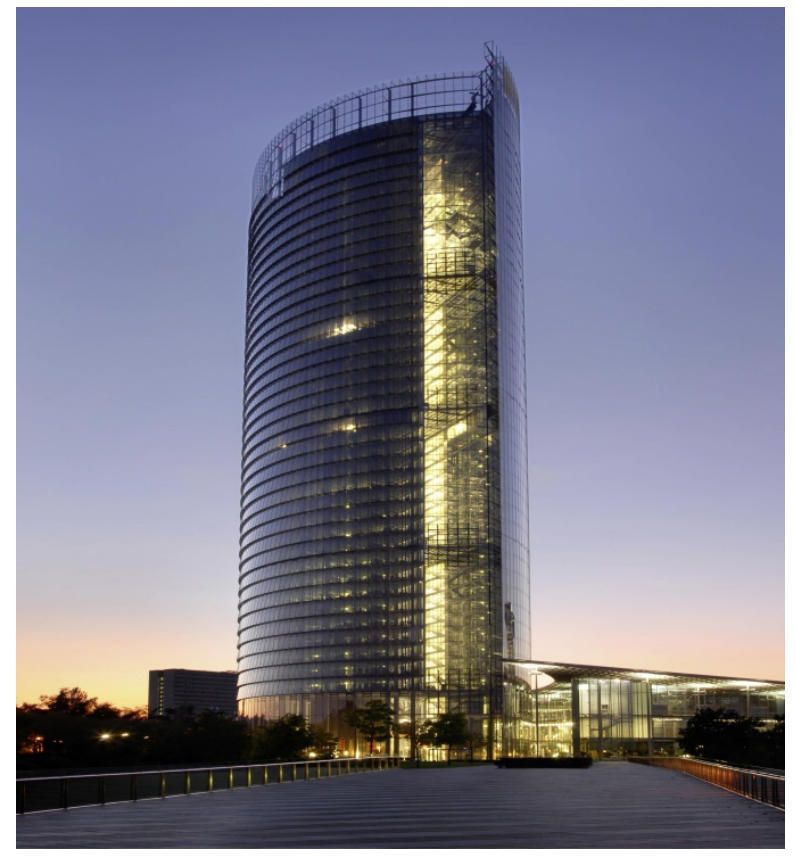

\section{Indoor Climate Control}

The ventilation system must be continuously activated in order to control the intensity of heat and light that enter through glass surfaces used on the facade of the buildings. The facilities that use nanomaterials in order to prevent heat and light from

Figure 2. Deutsche Post-Tower (URL3). 
entering the surface are divided into four headings, three of the solutions are active while one solution is passive. The passive solution method consists of thin coatings that absorb the undesirable infrared rays that cause the surfaces of buildings to heat up. Active solutions are provided by photochromic (light response), electrochromic (reaction to applied voltage) and thermochromic (heat response) methods. The substantial advantage in electrochromic methods is that the control is independent of the external effects. The tungsten oxide $\left(\mathrm{WO}_{3}\right)$ layer which is coated on glass surfaces by applying tension can absorb more infrared rays or glass can be convert to dark blue by adding hydrogen ion (Candemir et al.,2010).

Nanomaterials, which provide protection against ultraviolet rays, are formed using organic substances and certain additives. The appearance and color of the main material under the coating is not affected by the sun's rays, since the coatings, which keep the ultraviolet rays within the body and protect the material, have a transparent structure. In fact, the use of nanomaterials that provide protection against solar radiation minimizes the need for curtain. As a result of using nano-coating materials, energy is saved only by using electricity when needed (Lazim et al.,2008) and photochromic glasses make energy use more efficient (Figure 3).

Figure 3. Photochromic glass coating (URL4).

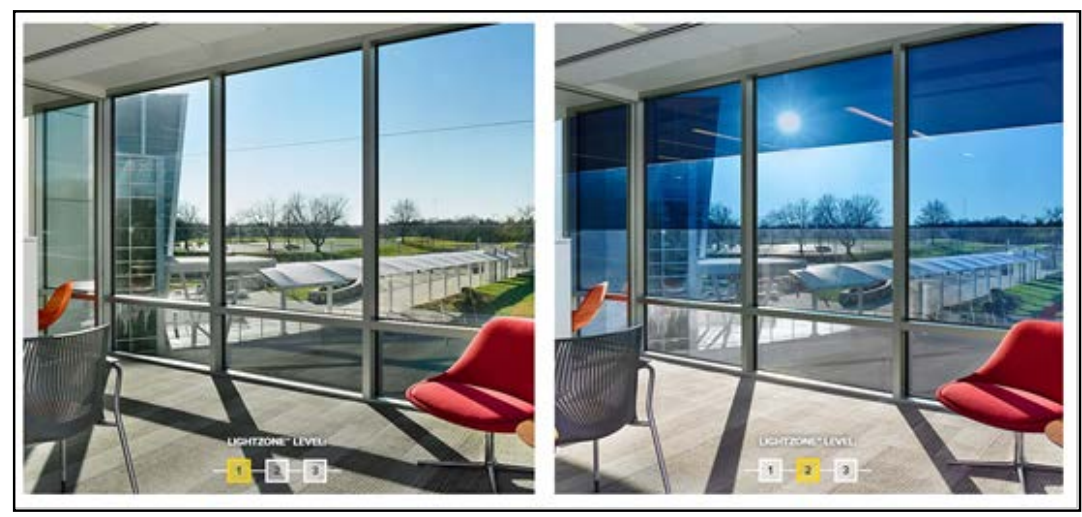

The thermochromic layer and the coated glasses change color as seen in Figure 4 according to the change of the atmospheric conditions in the outdoor environment, provide the adjustment of the energy requirements and temperature in the indoor environment. By reacting to light and heat exchange, the color change of the glass is happened due to the polymeric layer (Savic, 2013). Figure 4 shows the glass curtain wall system that has changed colors according to sunlight and temperature during morning, afternoon and evening. This effect is achieved by thermochromic glass coating, and energy saving is provided in indoor lighting and heating systems, also thermal insulation and visuality are obtained. 


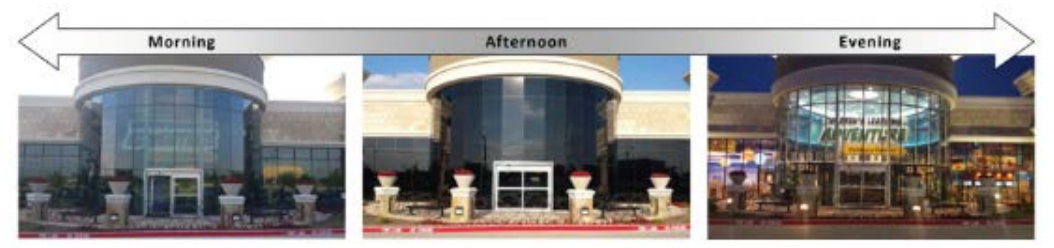

\section{Nano-products in Aluminum Composite Panel Curtain Wall} System and Some Projects

The coating application of glass, metal and ceramic surfaces with $\mathrm{TiO}_{2}$ has been patented under the name of HydroTect ${ }^{\circledR}$. The HydroTect ${ }^{\circledR}$ coating provides the ability to clean the air by neutralizing the nitrogen oxides in the air, in addition to the ability to self-clean with rain water. The $1000 \mathrm{~m}^{2}$ photocatalytic cladding is capable of cleaning as much as 70 trees can clean the air (Orhon, 2014). Two examples of structures where $\mathrm{TiO}_{2}$ coating used is the Bertram and Judith Kohl Building (Ohio, USA, 2010, Westlake Reed Leskosky-Figure 5) with photocatalytic aluminum panel and Monte Verde Tower (Vienna, Austria, 2004, Albert Wimmer-Figure 6) with photocatalytic ceramic panel applications.

LEED Gold certified Bertram and Judith Kohl Building is used as a music conservatory, and The Monte Verde Tower is used as a residence (Orhon,2014).

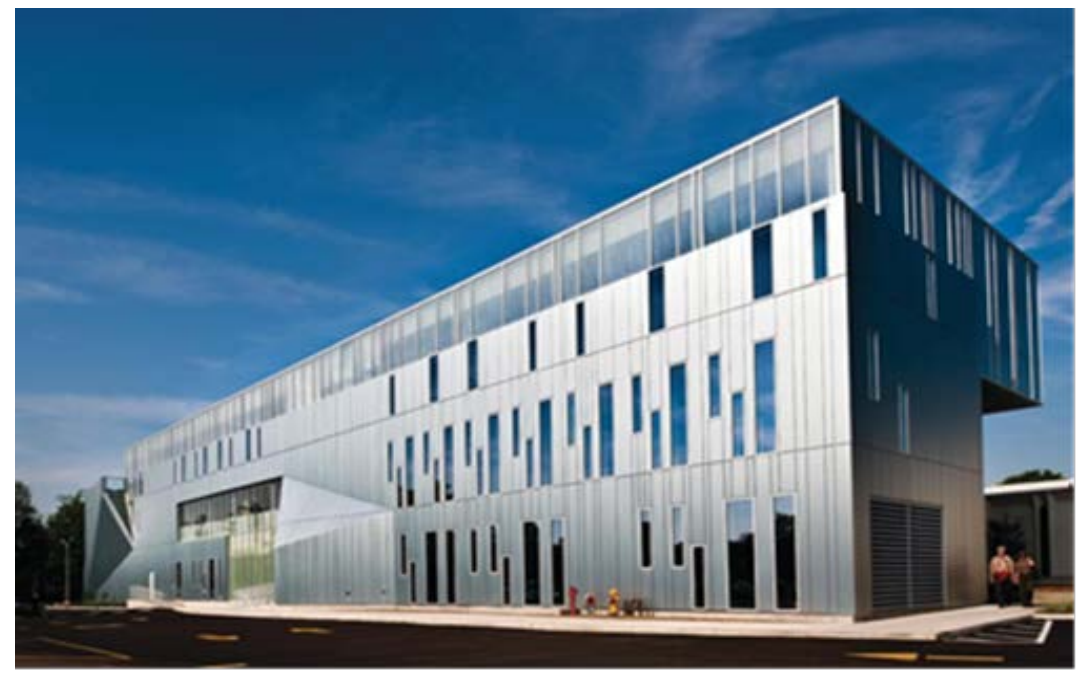

Aluminum composite materials manufactured by Mitsubishi Chemical Corporation have Class A fire resistant properties. Conventional fire-resistant surfaces for both interior and exterior walls can be produced with this material. The outer surface of this material is produced from an alloyed aluminum plate with a thickness of $0.5 \mathrm{~mm}$ while the filling material is made of a high content non-flammable mineral core filler. Facade of Renaissance Biz Plaza shown in Figure 7 can be given as an example project (Mitsubishi Chemical, 2018).
Figure 4. Morning, afternoon, and evening views of a thermochromic building (URL5).

Figure 5. Bertram and Judith Kohl Building photocatalytic aluminum facade (URL6). 
Figure 6. The Mont Verde aluminum facade (URL7).

Figure 7. Renaissance Biz Plaza aluminum composite facade (Istanbul) (URL8).
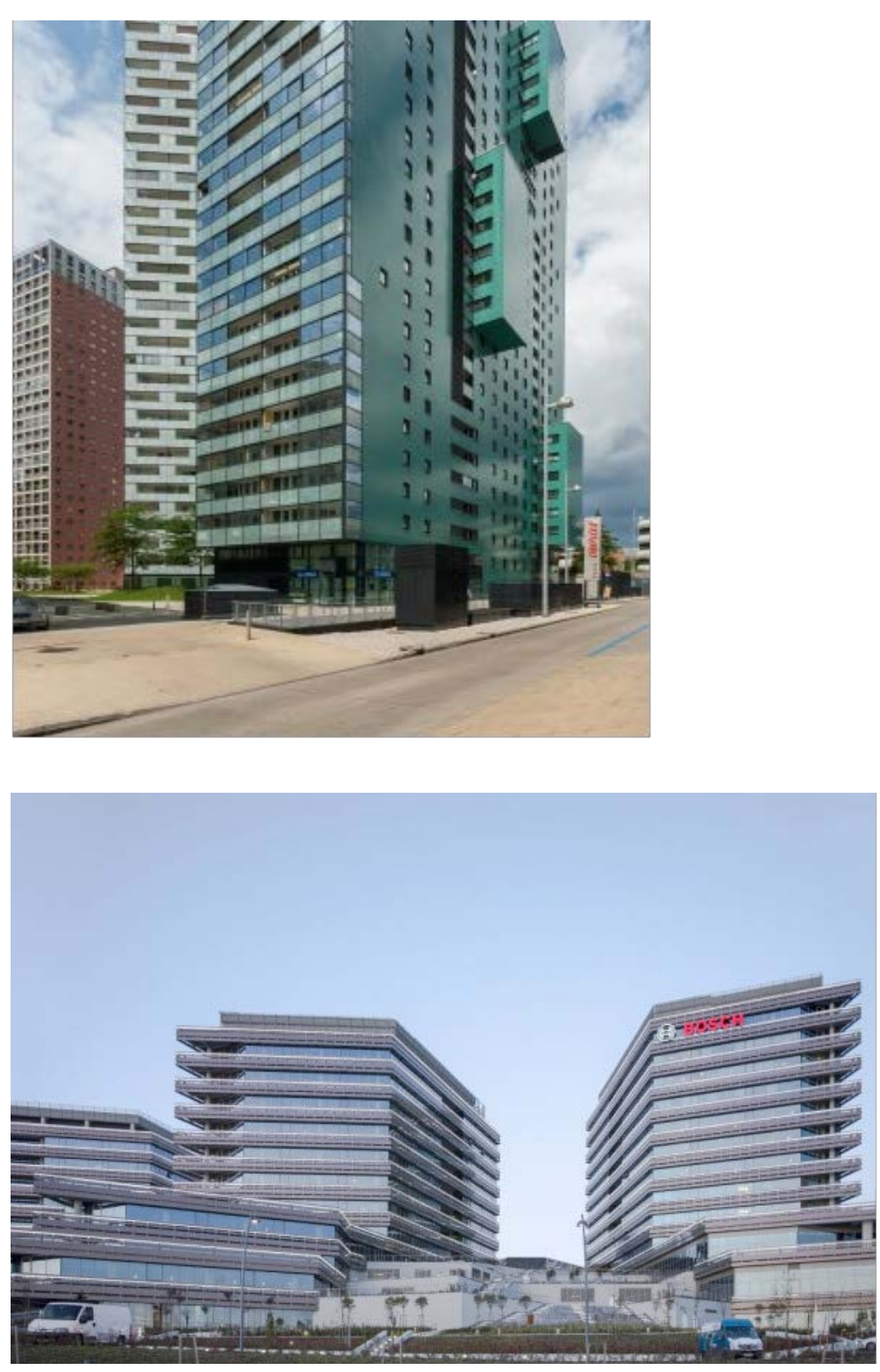

The molecular structure of the nano-coated composite panel's paint on the upper surface is changed, just like nano PVDF (polyvinylidene fluoride) panels. Thus, these panels have a selfcleaning feature and smooth surfaces. Nano PVDF panels are produced by using nano-polymers. The nano-coated surface of Nano PVDF panel does not retain any water or dirt. Thereby, the panels can remain clean for a longer period and can be easily washed in case of necessity. Also, any chemical that would be harmful to the nature is not required for cleaning. Figure 8 shows the building of the Spanish Power Company in Barcelona and, the Expo 2016 Tower in Antalya in Figure 9, are both used 
aluminum composite panels that can clean their facades and the air inside the buildings.
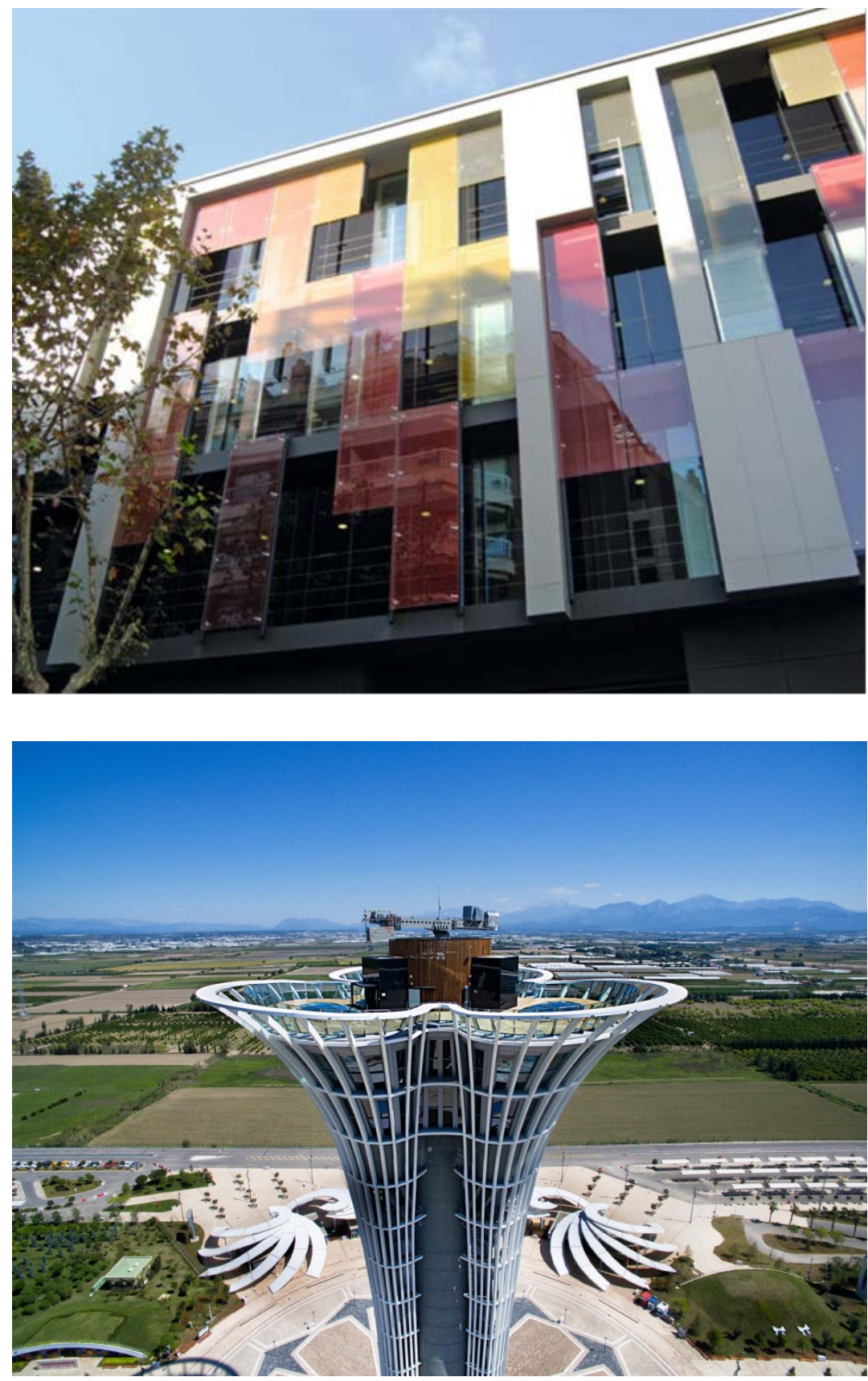

These types of curtain wall systems also contribute to sustainability by providing energy savings due to their photovoltaic properties.

\section{RESEARCH METHOD}

In the first part of this study, the nanomaterials used in buildings and their usage purposes have been discussed, and in the second part of the study, a survey has been conducted to examine which of these materials are used in the Turkish construction sector and to assess the level of nanotechnology awareness among the
Figure 8. Spanish Power Company Building (Barcelona) aluminum composite panel cladding (URL9).

Figure 9. Expo 2016 Antalya Tower aluminum composite panel curtain wall application (URL10). 
participants. Survey covers the suppliers of aluminum composite and glass curtain wall system. The questions related to nanotechnology in this research are directed to the general managers, managers, assistant managers, R\&D managers, marketing managers, consultants, quality managers, and architects in the companies. The people working in these positions are the target respondents of the survey which was distributed via e-mail to authorized company officials who agreed to participate in the research. Face to face interviews were made with those who could not be reached by e-mail. The survey that was formed by the authors was sent to 68 participants working in the aluminum composite and glass curtain wall companies operating in the construction sector. The return rate of the surveys is $85 \%$ (58 surveys).

\section{FINDINGS}

In total, 58 (85\% return rate) respondents answered the survey. The graphic that shows the positions of the survey participants is given in Figure 10.

Figure 10. Employee positions in the companies

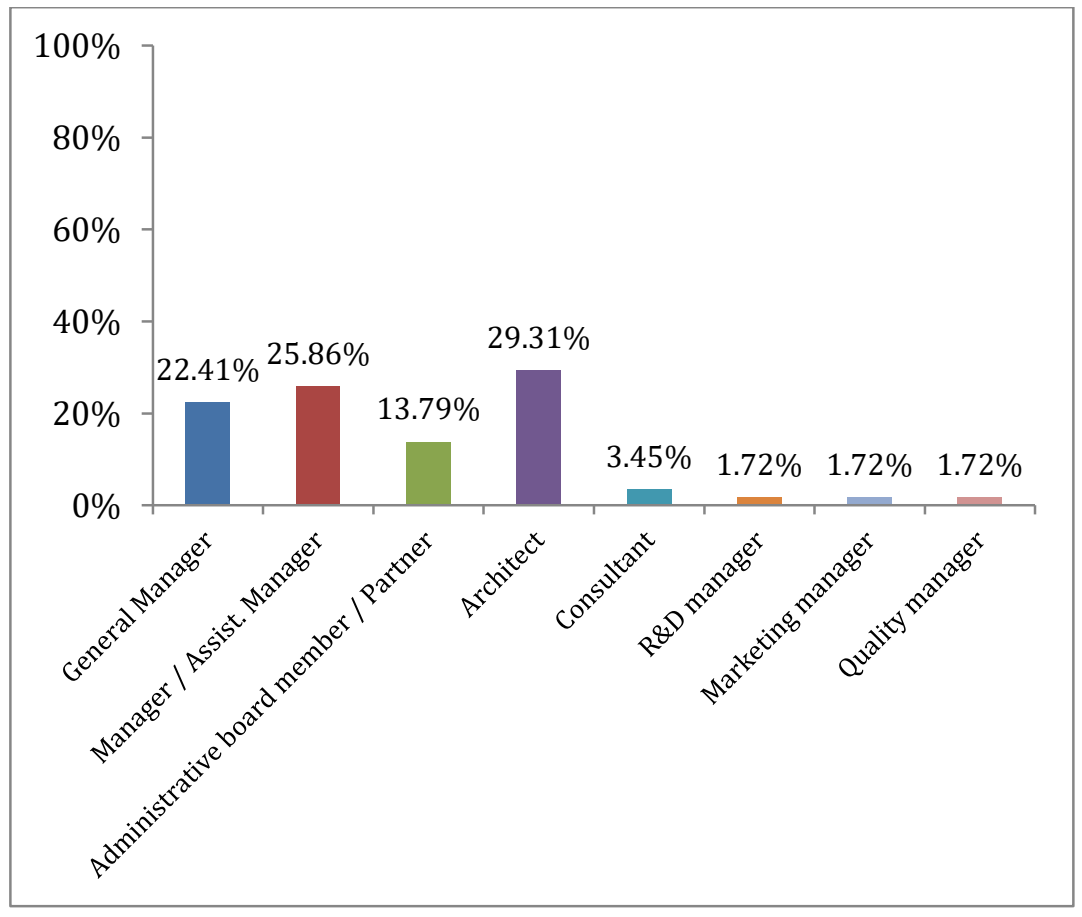

As seen in Figure 10, 29.31\% of the participants are architects, $25.86 \%$ are manager or assistant managers, $22.41 \%$ are general managers, $13.79 \%$ are board members / partners, $\% 3.45 \%$ are consultants, $1.72 \%$ are marketing manager, and $1.72 \%$ of them are quality managers.

Figure 11 shows the experience of the survey participants in the industry. $1.72 \%$ of the participants worked for $1-3$ years, $22.41 \%$ for $4-10$ years, $15.52 \%$ for $11-15$ years, $29.31 \%$ for $16-20$ years, 
while the remaining \%31.03 of them have been working in the sector for more than 20 years.

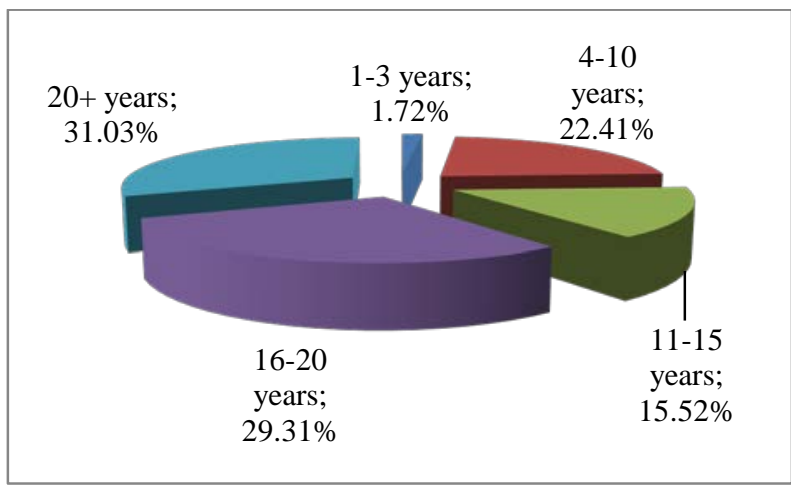

General characteristics of companies that made curtain wall systems are given in Figure 12 and Figure 13. Figure 12 shows the distribution of the institutional ages of the companies. As seen in here; $5.17 \%$ of companies are 0 to 5 years, $17.24 \%$ are 6 to 10 years, $12.07 \%$ are 11 to 15 years, $8.62 \%$ are 16 to 20 years, and $56.90 \%$ are in the sector for more than 21 years.

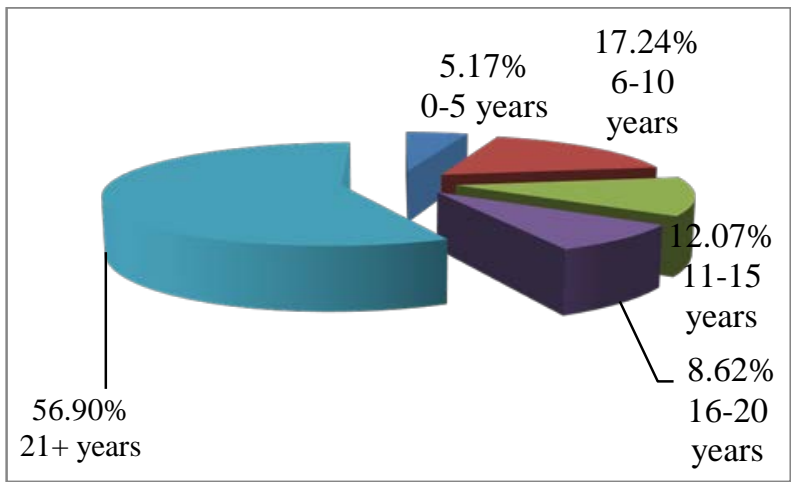

The distribution of the companies participating in the research by cities is given in Figure 13. 52 of the 58 companies operate in Istanbul, 2 in Kocaeli, 2 in Izmir, 1 in Tekirdag, and 1 in Ankara.

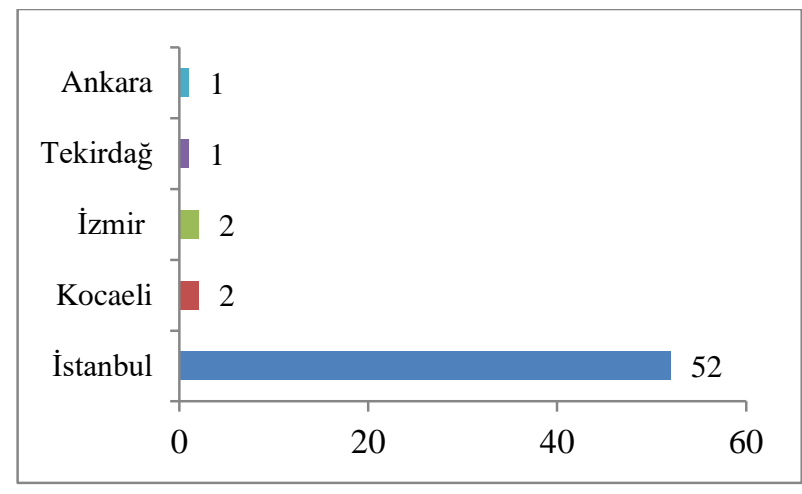

Figure 11. Distribution of employees' experience in the sector

Figure 12. Distribution of companies by institutional age

Figure 13. Distribution of companies by cities 
Figure 14 shows the market shares of companies in their core business. It is seen that $8.60 \%$ of them have a market share of over $60 \%$.

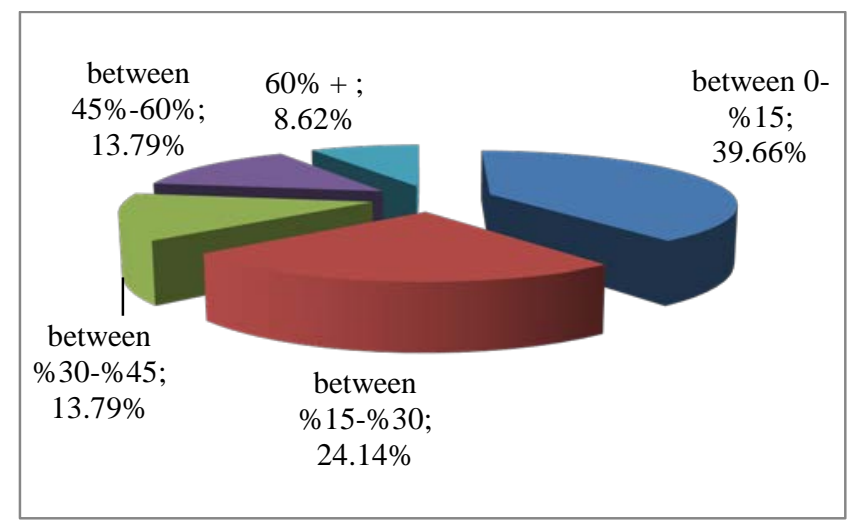

companies

Figure 15. Awareness levels of participants about Nanotechnology

Figure 16. Existence of R\&D Office on Nanotechnology in the company

Figure 15 shows the level of awareness of the participants about nanotechnology. $5.17 \%$ of the participants think that they are slightly aware about the subject, $44.83 \%$ are moderately aware, $5.17 \%$ are very aware and $1.72 \%$ are extremely aware, while $6.90 \%$ of the participants have no idea about the subject.

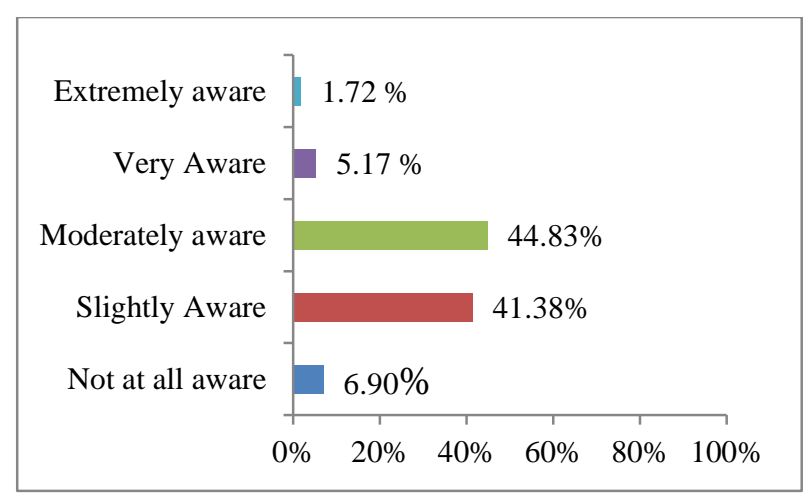

Figure 16 shows whether there is an R\&D department working on nanotechnology products within the companies. Only $15.52 \%$ of the companies have R\&D departments. $10.34 \%$ of them mentioned that an R\&D office has been considered in their companies in the near future.

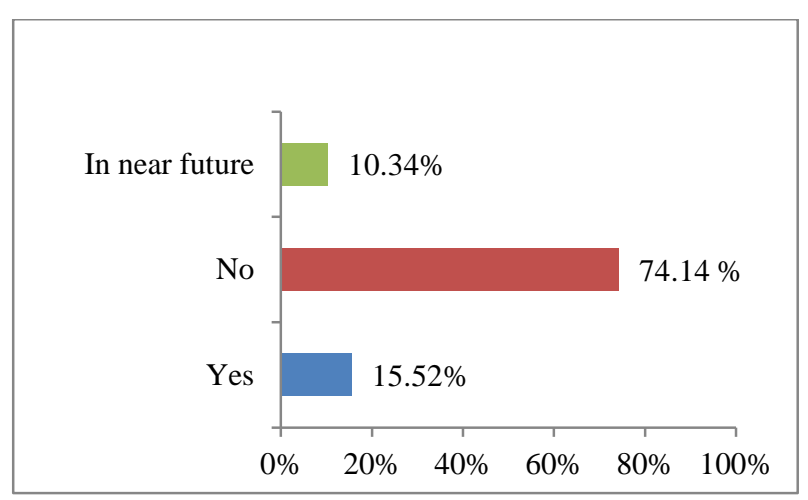




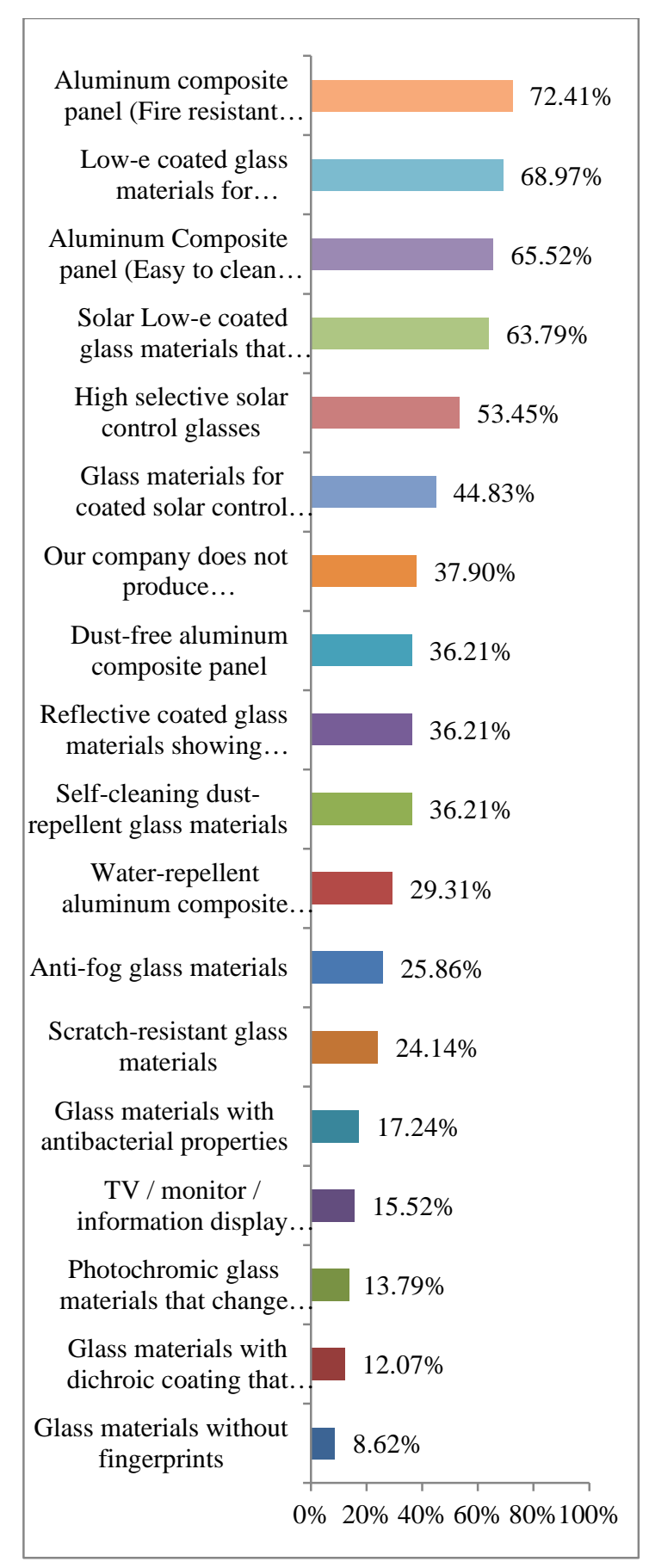

Figure 17 shows the types of nanotechnology-based building materials that the companies produce. It has been observed that $37.90 \%$ of them do not produce any nanomaterials. The most widely used nanomaterials are; fire resistant aluminum composite panels with $72.41 \%$, Low-e coated glass materials for temperature control with $68.97 \%$, and easy to clean aluminum composite panels with $65.52 \%$.

Figure 18 shows the factors that survey participants see as an obstacle to the use of nanotechnology-based materials. According to the responses of the participants; the most important three factors that prevent the use of nanomaterials in
Figure 17. Nanotechnological Building Materials 
the sector are the high cost of these products (68.97\%), contractors or investors not paying attention to the added value of nanomaterials (65.52\%), and inadequate technical support and consultancy on nanotechnology products (55.17\%).

Figure 18. Obstacles to the use of Nanotechnological Materials

Figure 19. Can companies with insufficient technical infrastructure receive support from universities or trade associations?

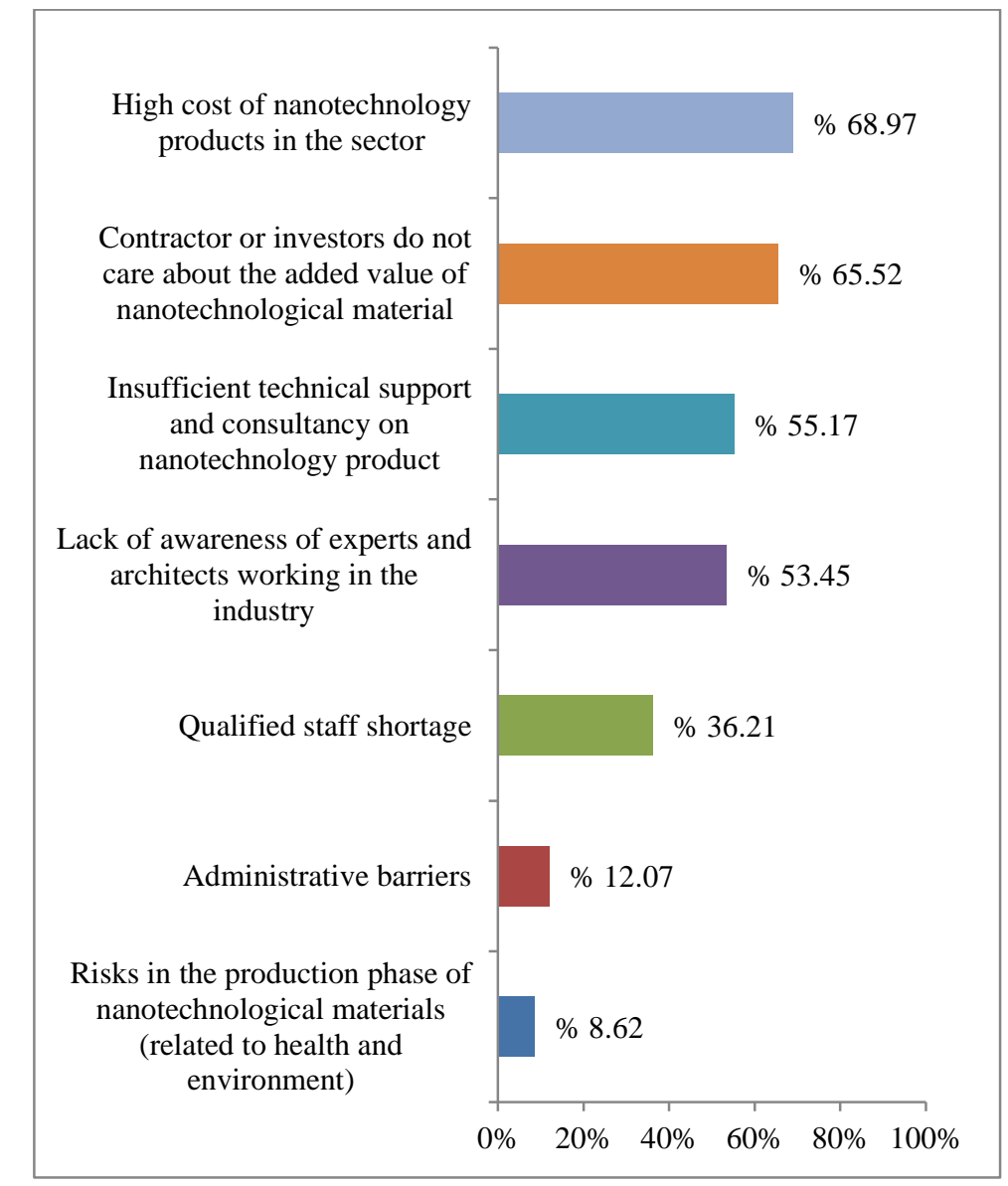

Figure 19 below shows whether companies without technical infrastructure can receive support from universities or trade associations related to the business. $70.69 \%$ of the participants stated that they could receive, while the remaining stated that they could not.

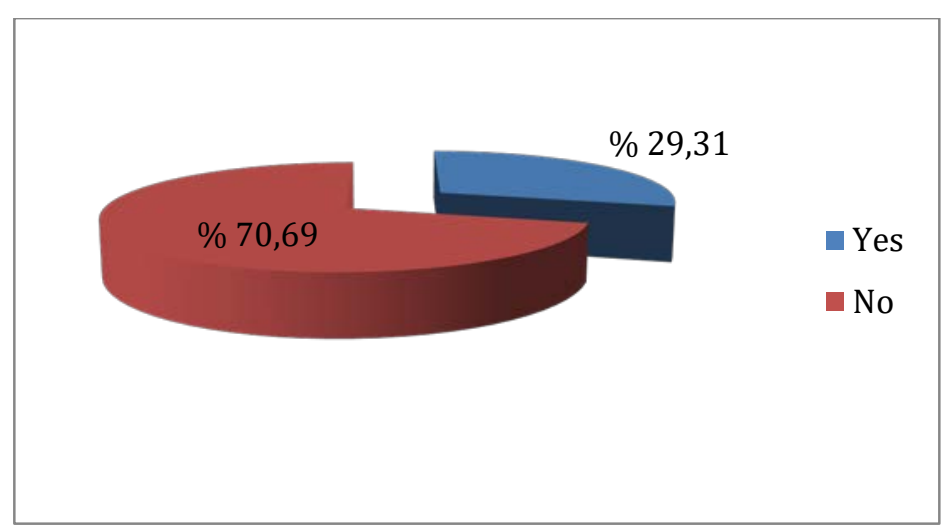


In the 11th question of the survey, the participants were asked, "Is it possible to reach institutions or organizations that can provide training in nanotechnology?" The answers given to this question are given in Figure 20 below. 56.90\% of the respondents answered no, while $43.10 \%$ answered yes.

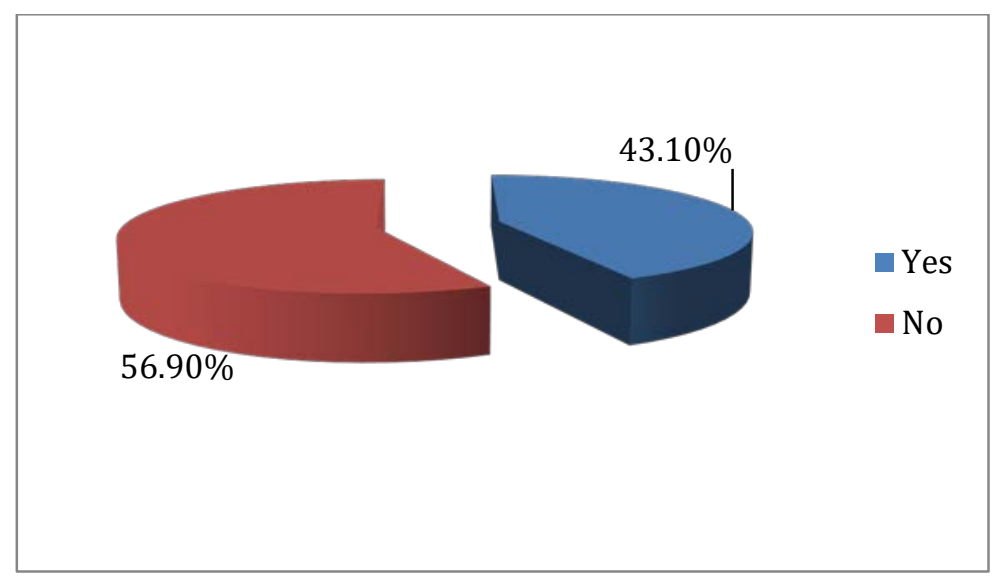

Figure 21 shows the opinions of the participants on the incentive support regarding the costs and education expenses related to nanotechnology. $74.14 \%$ of the participants said that there was no incentive, while $25.86 \%$ said it was an incentive.

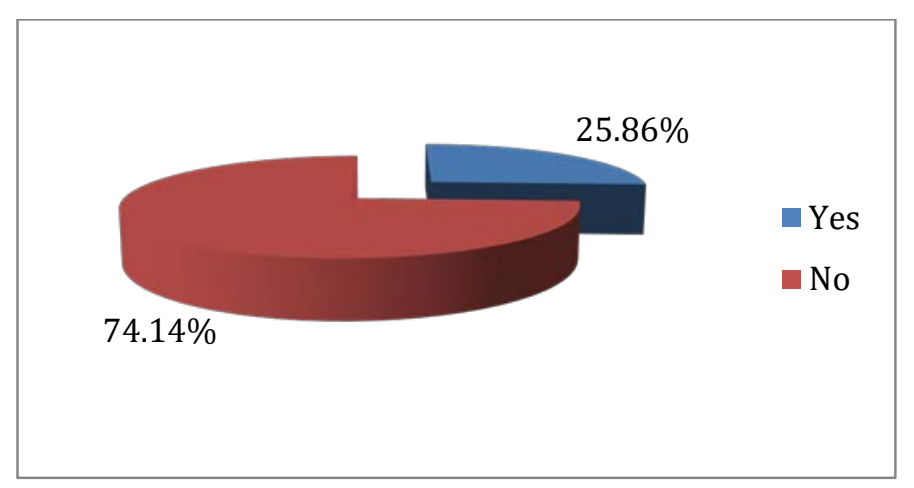

The answer to the question of "Is there any competent companies/institutions regarding the classification, quality, standard and performance evaluation of nanotechnology products?" is given in Figure 22. 65.52\% of the participants said no, while $34.48 \%$ said yes.
Figure 20. Is it possible to reach institutions or organizations that can provide training in nanotechnology?

Figure 21. Can incentive support be obtained for the costs and education expenses related to nanotechnology? 
Figure 22. Are there any competent companies/institutions regarding the classification, quality, standard and performance evaluation of nanotechnology products?

Figure 23. Indication of whether the participants agree or disagree with the statements given above (on a scale ranging from 1 - disagree to 5 - totally agree)

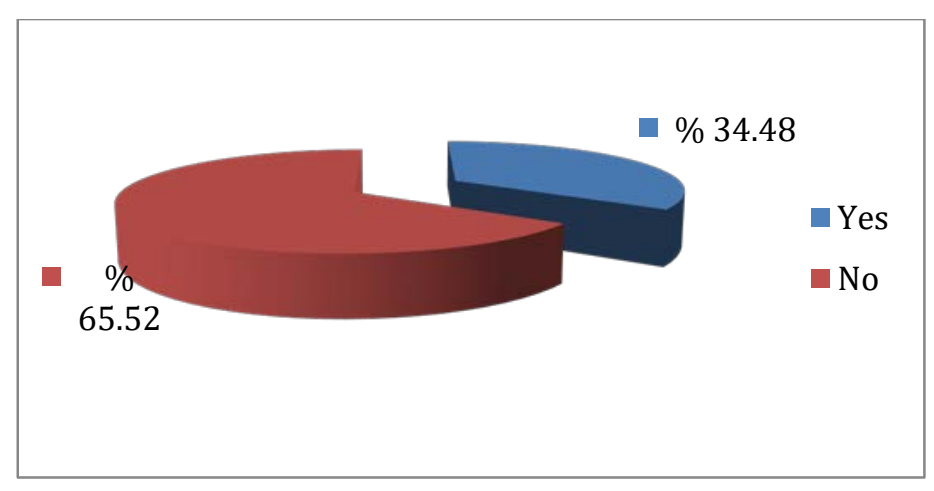

In Figure 23, the answers given by the participants on the 5point Likert scale are given to some statements asked in the survey. As the issue of sustainability is one of the most important issues of the agenda, the participants think that the adaptation of nanotechnology innovations is important (average $=3.88$ ). In addition, they think that nanotechnology innovations will be vital in global markets (average $=4.14$ ). Generally, it can be said that companies have made the necessary investments in nanotechnology (average $=3.31$ ). Also, it is obvious that studies on nanotechnology in this sector are extremely insufficient (average $=2.52$ ), and there are not enough experts or research groups working in this field in the companies (average $=2.41$ ).

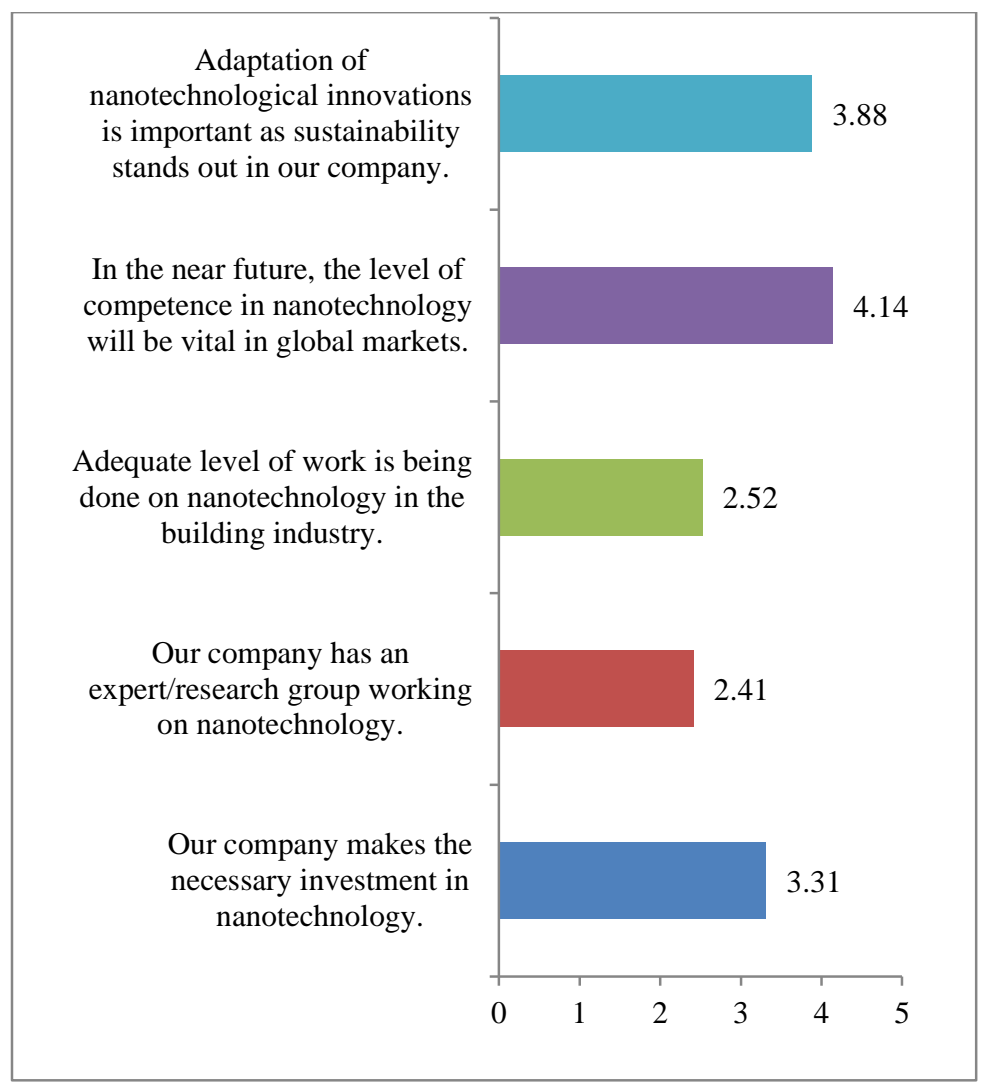




\section{DISCUSSION OF FINDINGS}

According to the survey, it is seen that the level of awareness of the participants about nanotechnology is not satisfactory. In parallel with the results of this study, some studies in the literature have also shown that one of the obstacles to the spread of nanotechnology in the construction sector is the lack of awareness of stakeholders regarding the opportunities offered by nanotechnology (Candemir, 2012). The results of this study show similarities with the results of the survey conducted by Van Broekhuizen's (2009). In the study, awareness of nanotechnology products is one of the important factors preventing the entry of nanotechnology products into the construction sector (Van Broekhuizen \& Van Broekhuizen, 2009). Although nanotechnology developments have attracted the current and future praise of academic and scientific world with their creative solutions, the increase in the use of nanomaterials and devices only can be realized with the understanding of the relationship between the value engineering and technological developments by the construction professionals (Bozoğlu \& Arditi, 2012).

There is no R\&D department in $74.14 \%$ of the companies that the participants work for. Most companies do not understand that innovation is one of the key factors in competition, so investing in research, development and innovation do not seem attractive to them (Serpell \& Alvarez, 2014). Since innovation is a very difficult and a painful process in the construction sector, companies generally do not want to take risks. Nanotechnology is seen as one of the most important technologies that will drive innovation in the construction sector (Genç et al., 2016). In some studies, insufficient R\&D investment is presented as one of the weaknesses of the sector (Forbes and Ahmed, 2011). Since the sector is not R\&D-oriented, R\&D activities related to nanotechnology in the curtain wall system take place in multinational companies or research institutes such as AKZONOBEL, DuPont and Heidelberg (Van Broekhuizen \& Van Broekhuizen, 2009). The Turkish construction sector is incompetent in innovation, and the government needs to lead the industry in innovation and R\&D. It is seen through studies that there is a lack of trust in the construction sector against new ideas and innovation. It is necessary to establish legal obligations and standards, and ultimately create an awareness of innovation (Genç et al., 2016). It is important to go beyond the financial incentives and supports for innovation and should take steps to create a culture of innovation in the long run.

The products benefiting from nanotechnology that used in curtain wall system, which are the subject of this study, are widely used throughout the world. However, they are not yet 
widely used in Turkey, and not preferred due to their high costs. According to the findings of this survey, the biggest obstacle to the use of nanotechnology products in the sector is the high costs. This finding is supported by Van Broekhuizens's (2009) study. According to the survey that covers 14 European countries indicate that the high cost of these materials is the most important factor preventing the access of nanotechnology products to the construction sector (Van Broekhuizen \& Van Broekhuizen, 2009). The cost of nanotechnology materials is relatively high compared to the cost of traditional building materials (Mann, 2006). In some studies, it is predicted that these costs will decrease over time as production technologies develop (Firoozi et al., 2014).

The negative effects on human health and the environment during the production of nanomaterials are not considered as significant obstacles for the application of nanotechnology products according to the participants (8.62\%). However, there are no standards related to these products in Turkey, and their effects on human health and the environment in the future are uncertain. It is thought that the positive or negative aspects of these products will rise more clearly and accurately with the increase of the studies and the service life of the nanotechnology products.

One of the findings of this survey shows that companies do not exchange enough information with universities and professional organizations. Only $29.31 \%$ of the companies stated that they could get some support. Likewise, companies are not getting enough support from institutions to obtain their employees trained on nanotechnology. R\&D activities for nanotechnology in Turkey are usually carried out through research centers at universities, and some specific institutions that supported by the public authorities. In addition, these activities are supported by studies within the scope of undergraduate and graduate programs involving researchers from many disciplines. One of the most important obstacles in establishing university-industry collaborations is the lack of information channels and information flow between both sides. This finding is also supported by the results of the Teizer et al.'s (2012) study which revealed a major gap between the construction sector and academia. This requires immediate attention (Teizer et al., 2012). It is important to enhanced interdisciplinary cooperation and follow the developments closely in order to reach international standards. It is critical for companies in the curtain wall sector to follow academic studies, and take big steps to improve nanotechnology through research studies with the universities. 
According to the survey findings, the participants are aware that nanotechnology will be an important competitive factor in the near future (average=4.14). This finding is supported by Andersen (2005) and Andersen \& Rasmussen's (2006) studies. According to the results of these studies (Andersen, 2005; Andersen \& Rasmussen, 2006), nanotechnology contributes to increase the innovation capacity and competitiveness of the sector.

The participants are aware of the potential contribution of nanotechnology to sustainability (average $=3.88$ ) as can be seen from the results of the survey. The construction sector is one of the leading sectors that have the worst impact on the environment and climate change, considering the high energy intensity of production and the negative effects of construction materials throughout the entire life cycle. Its potential contribution to sustainability makes nanotechnology one of the key innovations in green building. Nanotechnological building materials provide significant contributions to sustainability due to their energy efficiency and longevity, environmental friendliness, and contributing to the protection of the atmosphere.

According to the participants, companies in the curtain wall sector make the necessary investment for nanotechnology (average $=3.31$ ). Investments are vital for the access to market and adaptation of nanotechnology. Every investment in innovation takes companies to higher levels, increases their efficiency and strengthens them in global competition.

The participants think that there are not enough studies on nanotechnology in the sector (average=2.52). Research on nanotechnology is still in its infancy (Teizer et al., 2012). There are few experts or research groups working in the nanotechnology area (average $=2.41$ ). Recent developments in the field of materials will affect the architecture, especially the outer shell design (curtain wall) closely. According to Rao et al. (2015), developments starting with the application of nanotechnology will completely transform the construction sector. It is obvious that there is a need for experts and research groups working in this field in the sector, and the companies will need qualified personnel in order to compete.

\section{CONCLUSION}

Nanotechnology is considered as one of the twenty first century's important technologies. It is seen that most of the nanotechnology products used in the construction sector have been developed by companies working in the field of chemical and materials science. Potential of nanotechnology applications is growing in the construction field. There are large numbers of 
nanotechnology applications in the sector. However, construction sector is a traditional and cost oriented industry, rather than a technology focused sector. The low investment for research activities in the construction sector is a major obstacle to nanotechnology. For this reason, the adaptation of nanotechnology applications into the construction sector has been limited. The results of the survey in this study also support this.

The market of materials and technologies that are used in green buildings will be shaped with the demands of architects and building contractors rather than nanotechnology products suppliers. The minimum level use of harmful substances like detergents for cleaning glass and aluminum composite curtain wall systems is very important for environmental sustainability. Air pollution caused by toxic gases released into the atmosphere also causes adverse effects on the facades of the buildings which leads to dust, dirt and deterioration of the facade surfaces (composite panel coating, glass, etc.). For this reason, the maintenance of the products used in curtain wall systems is very important in terms of product lifetime. In addition to these, it is possible to state that maintenance and repair necessities can be reduced by choosing nanotechnology products which are manufactured for the facades like self-cleaning, fingerprint-free and scratch-resistant, etc. It also minimizes maintenance costs during the operation of structures. Furthermore, it can be said that it will contribute to the decrease of industrial accidents.

Although the nanomaterials have been used for the last 15 years in developed countries, their use in Turkey is relatively limited. While these materials are used in many different parts of the structures, the most preferred in the outer shell design of the buildings (curtain wall systems). It is anticipated that the building materials (nanomaterials, nanocomposites, etc.) and more different products with many new features can be developed thanks to nanotechnology which is the scientifically accepted technology of the century we live in.

Considering the interviews with relevant experts, manufacturers, vendors and end-users, it is possible to state that nanomaterials used in curtain wall system have many positive features compared to other facade products used. Also, it should be highlighted that the cost difference cannot be ignored. Nanotechnological materials have different applications according to their usage areas. These are often used in buildings built on principles of innovative and sustainable design (green building). The market share of nanomaterials is about $5 \%$ compared to other traditional building materials. 
Risks such as the standards regarding nanomaterials have not been fully established yet, and detection of harmful factors in some products cause questioning of nanotechnology. It is thought that the future will be shaped by nanotechnology with the resolution of these seemingly negative effects, including high costs of the products, and the lack of sufficient technical staff for maintenance and their long training period. Apart from many disciplines (such as medicine, pharmacy, chemistry, biology, physics), nanomaterials will shape the future by leading to significant developments and changes in the building industry which is one of the strategic sectors where nanotechnology can be applied. Since sustainability and energy efficiency have become imperatives, it should be considered that nanomaterials can increase the competitiveness of companies.

Some facts like high costs, custom production, difficult production processes in nanometric scales and not easy to observe the scale, lack of technical staff for maintenance and inspection, inspection requirements, complex maintenancerepair methods, identification of harmful substances in some products, and not fully established standards for nanomaterials lead to the questioning of nanotechnology. It is foreseen that future will be shaped by nanotechnology by resolving these seemingly negative effects. In addition to multidisciplinary (medicine, pharmacy, chemistry, biology and physics), nanomaterials in construction will lead to important developments and changes and will shape the future.

\section{ACKNOWLEDGEMENT}

This study is derived from first author's master thesis of Institute of Science and Technology, Balikesir University.

\section{REFERENCES}

Ali, A.A. (2020). Nanotechnology in civil engineering construction. International Journal of Structural and Civil Engineering Research 9(1),87-90.

Andersen, M.M. (2005). Embryonic innovation - path creation in nanotechnology. Paper for the DRUID Conference, June, Helsinore.

Andersen M.M. \& Rasmussen B. (2006). Nanotechnology development - environmental opportunities and risks, Ris $\varnothing$-R Report, Roskilde.

Bartos, P. J. M. (2009). Nanotechnology in construction: a roadmap for development. In Z. Bittnar, Bartos P. J. M., Nemecek J., Smilauer, V. and Zeman J. (eds.), Nanotechnology in construction: Proceedings of the NICOM3, 3rd International Symposium on Nanotechnology in Construction, Prague, 15-26. 
Bozoğlu, J. ve Arditi, D. (2012). Yapılarda ve yapım yönetiminde yanoteknoloji uygulamaları. 2. Proje ve Yapım Yönetimi Kongresi, 13 - 16 Eylül, İzmir Yüksek Teknoloji Enstitüsü, Urla-İzmir

Candemir, B., Beyhan, B. \& Karaata, S. (2012). İnşaat Sektöründe Sürdürülebilirlik: Yeşil Binalar ve Nanoteknoloji Stratejileri, Tüsiad Yayın No: TÜSİAD-T/2012-10/533

Daryoush B. \& Darvish A. (2013). A case study and review of nanotechnology and nanomaterials in green architecture. Research Journal of Environmental and Earth Sciences, $5(2), 78-84$.

Da Silva, L.F.M. Öchsner, A. \& Adams R.D. (eds.), (2011). Handbook of adhesion technology, Springer, Heidelberg.

Das, K. and Sen, S. \& Biswas, P. (2020). A review paper - on the use of nanotechnology in construction industry. January Available at SSRN https://ssrn.com/abstract=352671 6 or http://dx doi.org/10.2139/ssrn.3526716

Dixon, $\mathrm{W}$, (2010). The impacts of construction and the built environment. Briefing Notes, Willmott-Dixon Group.

Enshassi, A., Koshendoefer, B. \& Rizg, E. (2014). An evaluation of environmental impacts of construction projects", Revista Ingeniera de Construction, 29(3), 234-254

Firoozi A.A., Taha M.R., \& Firoozi A.A. (2014). Nanotechnology in civil Engineering, Electron J Geotech Eng, 19:4673-4682.

Forbes, L. H. \& Ahmed, S. M. (2011). Modern construction, lean project delivery and integrated practices, Boca Raton, FL: CRC Press, Taylor and Francis.

Genç, O , Bozkurt, A , Coşkun, H., \& Erdiş, E . (2016). Türkiye inşaat endüstrisindeki inovasyon düzeyinin inşaat mühendisliği penceresinden görünümü. Çukurova Üniversitesi Mühendislik-Mimarlık Fakültesi Dergisi 30 (2) , 183-190.

Gür, M. (2010). Nanomimarlık bağlamında nanomalzemeler. Uludă̆ Üniversitesi Mühendislik-Mimarlı Fakültesi Dergisi, Cilt 15, Sayı 2, 81-90.

Halicioglu, F. H. (2009). The potential benefits of nanotechnology for innovative solutions in the construction sector. Nanotechnology in Construction 3., Springer, Heidelberg, 209-214.

Hossain, K. \& Rameeja, S. (2015). Importance of nanotechnology in civil engineering. EJSD, 4: 161-166.

Lazim, N. A., Asim, N., Rani M.A.A., Ahmadzadeh, A., Yarmo, M.A., \& Radiman, S. (2008). Investigation of nanoscale tungsten (VI) oxide as a catalyst for the ozonolysis of oleic acid. European Journal of Scientific Research, 24 (4), 463-467. 
Lee, J., Mahendra, S. \& Alvarez, P.P.J. (2010). Nanomaterials in the construction industry: a review of their applications and environmental health and safety considerations. ACS NANO, 27;4(7):3580-90.

Mann S. (2006). Nanotechnology and construction, Nanoforum Report, 1-55.

Mitsubishi Chemical Euro Asia, (2018). Alpolic broşür, Mitsubishi Chemical Euro Asia. Türkiye

Niroumand, H., Zain, M. F. M., \& Jamil, M. (2013). The role of nanotechnology in architecture and built environment. Procedia - Social and Behavioral Sciences, 89(0), 10-15.

Olafusi, O. S., Sadiku, E.R., Snyman, J. et al. (2019). Application of nanotechnology in concrete and supplementary cementitious materials: a review for sustainable construction. SN Appl. Sci. 1, 580. https://doi.org/10.100 7/s42452-019-0600-7

Orhon, A. V. (2014). Sürdürülebilir çatı ve cephe sistemleri, 7. Ulusal Çatı \& Cephe Sempozyumu, 3- 4 Nisan,Yıldız Teknik Üniversitesi, İstanbul

Özenbaş,M., (2006). Nanoyapılı malzemeler ve nanoteknoloji. Bilim ve Teknoloji Stratejileri Çalıştayı, 31 Mayıs-1 Haziran, 2.

Raj, B., Van de Voorde, M. \& Mahajan, Y. (2017). Nanotechnology for Energy Sustainability (3 Volume Set), John Wiley \& Sons, Hoboken, NJ.

Rao, N. V. Rajasekhar, M. Vijayalakshmi, K., \& Vamshykrishna, M. (2015). The future of civil engineering with the influence and impact of nanotechnology on properties of materials. Procedia Materials Science, 10, 111-115.

Savić, J., Đurić-Mijović, D., \& Bogdanović, V. (2013). Architectural glass: types, performance and legislation. Facta universitatis-series: Architecture and Civil Engineering, 11(1), 35-45.

Serpell, A., \& Alvarez, R., (2014). A systematic approach for evaluating innovation management in construction companies. Procedia Engineering, 85: 464-472.

Sev, A \& Ezel, M. (2014). Nanotechnology innovations for the sustainable buildings of the future. World Acad Sci Eng Technol Int J Civil Environ Struct Constr Architectural Eng, 8(8), 886-896.

Taniguchi N. (1974). On the basic concept of nanotechnology. Proceedings of the International Conference on Production Engineering, Tokyo, 18-23.

Teizer J., Venugopal M., Teizer W., \& Felkl, J. (2012). Nanotechnology and its impact on construction: bridging the gap between researchers and industry professionals. J Constr Eng Manag, 138:595-604. 
Tepe, A. (2007). Nanoteknolojide nano ölçekteki yapıların yerel olmayan elastisite çerçevesinde incelenmesi, İTÜ, Fen Bilimleri Enstitüsü

Tülübaş Gökuç, Y. \& Turunç S. (2019). Use of nanotechnological building materials in the Turkish construction industry. $J$ Sustain. Construct. Mater. Technol. 4(1),296-305.

Van Broekhuizen, F. \& Van Broekhuizen, P. (2009). Nanoproducts in the European construction industry. European Federation of Building and Wood Workers and European Construction Industry Federation, 1-109.

Zhu, W., Bartos, P. J., \& Porro, A. (2004). Application of nanotechnology in construction, Materials and Structures, 37(9), 649-658.

URL1: https://www.nanowerk.com/nanotechnology/reports/re portpdf/report72.pdf (15.12.2018)

URL2: http://www.anbonano.com.tr/camyuzeykoruma.html (12. 01.2019)

URL3: http://www.spannverbund.de/index.php/en/post-towerbonn.html (17.12.2018)

URL4: https://www.glassonweb.com/article/role-adaptive-faca des

URL5: https://www.commercialwindows.org/thermochromic.ph $\mathrm{p}(02.01 .2019)$

URL6: https://www.architectmagazine.com/design/buildings/b ertram-and-judith-kohl-building_o (26.01.2019)

URL7: https://www.mimoa.eu/projects/Austria/Vienna/Monte \%20Verde\%20Tower (13.02.2019)

URL8: https://biozet.com/2015/11/16/projeronesansbiz-kucuk yali-ofis-park (17.12.2019)

URL9: http://trends.archiexpo.com/arconic-architectural-prod ucts-merxheim-frankreic/project-67104-227013.html (23.01.2019)

URL10: http://www.arkitera.com/proje/7282/expo-2016antaly a-expo-kulesi2 (02.02.2019) 


\section{Resume}

Dr. Yeliz Tülübaş Gökuç has degree M. Arch. from Balikesir University. She also obtained her PhD degree in Architecture from Mimar Sinan Fine Arts University. She experienced a post doctoral research as a visiting scholar at IIT, Chicago, USA . She is currently working as assistant professor at Balikesir University.

Osman Zeki Şahin is MSc student in Architecture in Balikesir, Turkey. He got his B. Sc. degree in Architecture at Karadeniz Technical University. He is currently working as architect Balikesir Metropolitan Municipality. 